\title{
INNOWACYJNE PROCESY DRUKU 3D - ANALIZA RYZYKA WDROŻENIA INNOWACJI W BRANŻY STOMATOLOGICZNEJ
}

\begin{abstract}
Streszczenie: Branża medyczna jest oceniana jako jedna z bardziej nowoczesnych dziedzin gospodarki wymagających stosowania zaawansowanych technologii. Jednocześnie spełnienia wysokich oczekiwań społecznych dotyczących wprowadzania na rynek nowych sposób poprawiania stanu zdrowia pacjentów. Obecnie obserwuje się ciągły postęp w dziedzinie druku 3D, a możliwości aplikacyjne w przyszłości stworzą bardzo wartościowy rynek. Artykuł przedstawia analizę branży stomatologicznej, implementację nowoczesnego rozwiązania - druku 3D w wybranej klinice stomatologicznej, zapoznanie z systemami pracy drukarek 3D, macierz BCG do oceny możliwości rynkowych oraz przedsiębiorstwa, rozbudowaną analizę otoczenia SWOT oraz TOWS, kalkulację ceny produktu.
\end{abstract}

Słowa kluczowe: innowacje, druk 3D, stomatologia, protetyka, analiza SWOT

\section{Wprowadzenie - znaczenie innowacji w protetyce i stomatologii}

Drukowanie 3D to sposób wytwarzania, w którym materiał, taki jak tworzywo sztuczne lub metal osadza się na siebie warstwami w celu wytworzenia trójwymiarowego detalu. Do tej pory, druk 3D stosowany był podczas prototypowania w technice. Dzięki rozwojowi zarówno w branży technologicznej, jak i stomatologicznej znalazł on zastosowanie przy wytwarzaniu elementów protetycznych. Innowacje mają w branży charakter ciągły - wprowadzanie ich wymaga niewielkiej zmiany zachowań. Wyróżnić już można drukowane elementy takie jak: podbudowy koron zębowych, protezy szkieletowe, nakładki oraz retainery ortodontyczne, modele stomatologiczne (WAGNER L. 2008).

\footnotetext{
${ }^{1}$ dr inż., Politechnika Częstochowska, Wydział Zarządzania, Instytut Inżynierii Produkcji, e-mail: klimt@wip.pcz.pl

2 inż., Politechnika Częstochowska, Koło Naukowe „Promotor Jakości” przy Instytucie Inżynierii Produkcji e-mail: katarzynakapustka@op.pl
} 
Druk 3D jest to technologia produkcji obiektów metodą przyrostową polegającą na nakładaniu się kolejnych warstw materiału. Poprzez zastosowanie narzędzi do projektowania przestrzennego 3D obiekt fizyczny zostaje wcześniej opracowany. Innowacja oddziałuje w obszarze marketingu na produkt. Sama istota produkt nie zmienia się, zostają udoskonalone tylko niektóre właściwości użytkowe, które korzystnie wpływają na jakość oraz skrócenie czasu wykonania. Podczas tradycyjnych metod produkcji za pomocą CAD (ComputerAided Design) proces opierał się na cięciu obiektów z większych lub z arkuszy materiału. Stereolitografia tworzy produkty w procesie addytywnej produkcji elementów. Dowiedziono, iż konwencjonalne metody są mniej efektywne, a koszty produkcji dzięki drukowaniu zostają znacznie zmniejszone. Wprowadzenie metod stereolitograficznych do gabinetów stomatologicznych określić można innowacją sprzężoną, gdyż wymaga wspólnego wysiłku większej liczby osób, a nawet zespołu specjalistów - inżynierów stomatologicznych, inżynierów biomateriałów, inżynierów ds. budowy maszyn, stomatologów, techników dentystycznych. Wymóg sprzężenia działań wynika ze złożoności techniki, jej coraz wyższego poziomu, podziału pracy i specjalizacji pracowników. Ze względu na debiutującą technologię w branży stomatologicznej konieczne jest przenikanie się nauki oraz techniki i produkcji. Druk 3D w gabinecie stomatologicznym jest innowacją na światową skalę, gdyż podobne rozwiązania są już stosowanie w stanach zjednoczonych oraz jednostkowo w Anglii, ale wykorzystywane wyłącznie na potrzeby laboratoriów protetycznych. Innowacją staje się wprowadzenie jej do gabinetu stomatologicznego, który uzyskuje możliwość stania się autonomiczną jednostką (BRUNELLO G. 2016).

\section{Analiza ryzyka wdrożenia innowacji w gabinecie stomatologicznym}

Obszar działalności, w ramach którego pojawia się propozycja wdrożenia innowacji obejmuje metody przyrostowe w gabinecie stomatologicznym. Celem pracy jest przedstawienie analizy ryzyka wdrożenia in- 
nowacji w branży stomatologicznej jest, czyli wprowadzenie drukarek 3D wraz $\mathrm{z}$ systemami do zastosowania przy produkcji indywidualnej w stomatologii oraz protetyce na przykładzie rynku niemieckiego.

Zakres pracy obejmuje analizę rynku niemieckiego w branży stomatologicznej przy wykorzystaniu analizy zasobów materialnych- zapoznanie się z systemami pracy drukarek 3D, macierz BGC, analiza SWOT oraz TOWS otoczenia, kalkulacja ceny produktu.

Główna działalność rynkowa kliniki stomatologicznej to utrzymanie wysokiego, profesjonalnego poziomu świadczonych usług w zakresie ochrony zdrowia. Stałe wdrażanie oraz rozwijanie nowych usług w dziedzinie stomatologii. Wykorzystywanie szkoleń pracowników dla podnoszenia standardów udzielanych świadczeń medycznych.

Struktura organizacyjna kliniki stomatologicznej opiera się na budowie liniowej- płaskiej. Największe kompetencje posiada właściciel kliniki, będący też głównym lekarzem. Władza jest scentralizowana. Plusem struktury płaskiej jest duża samodzielność pracowników.

Obszar w ramach którego zostanie wdrożona proponowana innowacja jest to obszar obejmujący część świadczonych usług medycznych a dokładnie opartych na leczeniu diagnostycznym, protetycznym, implantologicznym oraz zachowawczym. Diagnostyka polega na wydruku modelu diagnostycznego obrazującego uzębienie pacjenta. Model ten jest konieczny do dokonania niezbędnych pomiarów przy leczeniu protetycznym lub ortodontycznym.

Za pomocą druku 3D wykonywane będą nakładki wykorzystywane do leczenia starć patologicznych-bruksizmu. Jest to schorzenie występujące równie często jak miażdżyca, uznane za chorobę cywilizacyjną. Spowodowane przede wszystkim stresem-napięciami czego efektem jest ścieranie warstw tkanek twardych zębów (BRUNELLO G. 2016).

W nowoczesnej ortodoncji wykorzystuje się również specjalne nakładki ortodontyczne, które mają za zadanie korygowanie niewielkich wad zgryzowych. Ich tworzenie możliwe jest wyłącznie przy użyciu drukarek 3D. Są one dostosowane do indywidualnych warunków występujących w jamie ustnej pacjenta. Natomiast w ostatniej fazie leczenia orto- 
dontycznego w celu ustabilizowania uzyskanego efektu stosuje się nakładki retencyjne. Wykonywane również za pomocą druku stereolitograficznego.

Innowację wprowadzaną do gabinetu stomatologicznego można uznać zarówno za technologiczną jak i organizacyjną. Z innowacją technologiczną związane jest wprowadzenie nowych maszyn oraz technologii. Natomiast z organizacyjną wiąże się zmiana sposobu pracy, przyjęcie wyspecjalizowanego personelu oraz większa niezależność kliniki, gdyż prace do wykonania przestają być wysyłane do zewnętrznego laboratorium protetycznego. Samodzielnie stworzony zostaje nowy dział, który jest integralnie połączony z pracą kliniki.

\section{Kalkulacja ceny produktu}

Kosztorys sporządzony został dla przychodni stomatologicznej. Kalkulacja dotyczy ,modeli protetycznych wykonywanych metodą wydruku 3D”. Rozpoczęcie wprowadzenia zaplanowano na wrzesień 2016.

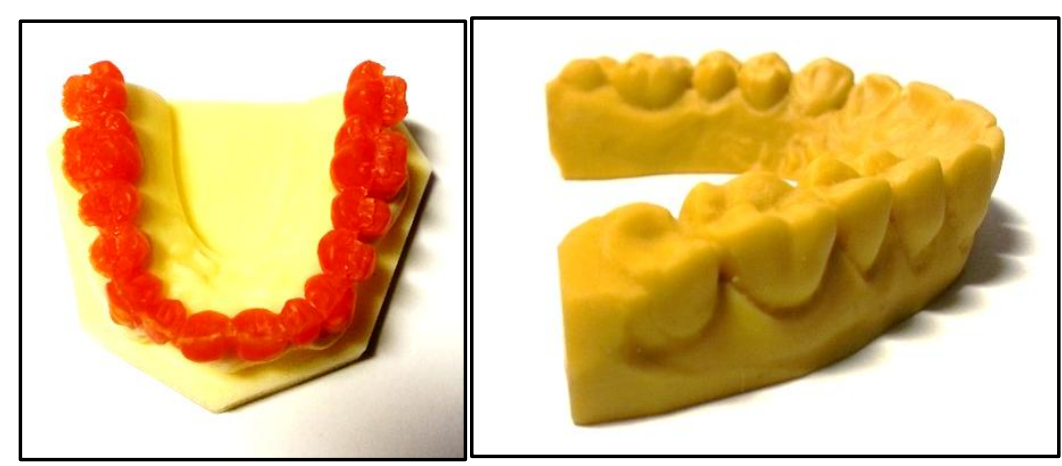

Rys. 1. Zdjęcie pogladowe produktu

Cykl produkcyjny podzielono na sześć kluczowych etapów:

Etap 1 - pobranie skanu jamy z ustnej pacjenta;

Etap 2 - przesłanie danych do serwera;

Etap 3 - przygotowanie wydruku; 
Etap 4 - wydruk 3D;

Etap 5 - oczyszczenie modelu;

Etap 6 - transport do odpowiedniego gabinetu.

Planowanie kalkulacji obejmuje uwzględnienie poszczególnych zadań niezbędnych do wykonania zamierzonego produktu oraz przygotowano kalkulację miesięcznych kosztów (tabela 1) i ceny produktu (tabela 2). Wyszczególnione zadania:

- kalkulacja cen produktu,

- określenie nakładu,

- zestawienie i zamówienie materiałów,

- planowanie pracy na poszczególnych stanowiskach roboczych,

- wydanie dokumentacji.

Tabela 1. Koszty dzialania (miesięczne)

\begin{tabular}{|c|c|c|}
\hline Koszty & Rodzaj & Suma kosztów , $€$ \\
\hline Pracownicy & $1 \mathrm{os} \times 15 \mathrm{zt} / \mathrm{h} \times 160 \mathrm{~h}-$ pracownik umysłowy & 2400,00 \\
\hline Materialy & Materiały & 200,00 \\
\hline $\begin{array}{l}\text { Energia } \\
\text { elektryczna }\end{array}$ & $\begin{array}{c}8 \mathrm{~h} \times 25 \mathrm{KW} \times 0,26 z \mathrm{z} / \mathrm{KWh} \times 20 \mathrm{dni}+\text { przesył energii } \\
\text { elektrycznej }\end{array}$ & 1140,00 \\
\hline Amortyzacja & $\begin{array}{l}\text { Pomieszczenie, Meble biurowe, Komputery itp. Sprzęt } \\
\text { biurowy }\end{array}$ & 600,00 \\
\hline Czynsz & Koszta utrzymania maszyny & 120,00 \\
\hline Pozostałe & $\begin{array}{l}\text { Abonament telefoniczny, Internet, Stworzenie dokumen- } \\
\text { tacji w wersji papierowej }\end{array}$ & 250,00 \\
\hline Suma & & 4710,00 \\
\hline
\end{tabular}

Źródło: opracowanie własne

Tabela 2. Kalkulacja ceny produktu

\begin{tabular}{|c|l|l|l|}
\hline Lp. & Typ procesu & Koszt, $\boldsymbol{€}$ & Koszt jednostkowy, $€$ \\
\hline $\mathbf{1}$ & Planowanie procesu produkcji & 4710.00 & 9.42 \\
\hline \hline \multicolumn{3}{|l|}{} \\
\hline $\mathbf{2}$ & Suma kosztów & 4710.00 & 9.42 \\
\hline $\mathbf{3}$ & Marża (zysk 80\%) & 3768.00 & 7.58 \\
\hline $\mathbf{4}$ & Cena końcowa & 8478.00 & $\mathbf{1 7 . 0 0}$ \\
\hline
\end{tabular}

Źródło: opracowanie własne 


\section{Analiza atrakcyjności sektora metodą 5 sil Portera}

Rozważając strategię działania przedsiębiorstwa (w tym wypadku gabinetu stomatologicznego) trudno nie wspomnieć o analizie strategicznej odnoszącej się do pięciu czynników, które są rozpatrywane podczas oceny atrakcyjności z uwzględnieniem szans i zagrożeń. W tym wypadku analiza uwzględnia takie czynniki jak:

a) sila przetargowa dostawców - w przemyśle medycznym na rynku niemieckim wzrasta liczba firm specjalizująca się w wytwórstwie materiałów i sprzętów stomatologicznych. To sprawia, że dostawcy konkurują o sprzedaż u klienta, a co za tym idzie obniżają ceny. Jednak wraz $\mathrm{z}$ obniżką ceny często $\mathrm{w}$ specjalistycznych produktach obniża się również jakość. Dlatego wielu dostawców nie pozwala sobie na takie zabiegi, co za tym idzie na rynku ceny są zrównoważone poprzez poszczególnych dostawców.

b) bariery wejścia na rynek - bariery wejścia na rynek, w szczególności w branży specjalistycznej z zakresu medycyny są wysokie, firma musi posiadać duży kapitał oraz wyspecjalizowaną obsługę. Profesjonalnie wykonywany zakres usług łączy się z dużym nakładem na ciągłe ulepszanie technologii. W dziale usług medycznych istotna jest również ciągła dbałość o jakość wykonywanych usług. $\mathrm{O}$ zaangażowanie podczas obsługi pacjentów i zapewnianie im najlepszych usług.

c) sila przetargowa odbiorców - obecnie na rynku występuje duże zapotrzebowanie na usługi stomatologiczne na całym świecie. Pacjenci wybierający renomowane jednostki posiadają wyższe wymagania wobec nich. Wybór na rynku przychodni charakteryzujących się jednak dostosowaniem pod pacjenta jest nie wielki. Jednak to $\mathrm{w}$ dużej mierze zależy od pacjenta które miejsce wybierze i jakimi parametrami będzie charakteryzował się jego wybór. Liczba pacjentów którą przyjmuje poszczególna przychodnia jest mocno uzależniona od pacjentów i ich wymagań. 
d) groźba pojawienia się nowych produktów - przemysł usług stomatologicznych nie jest mocno uzależniony od nowych usług. Rynek co roku wprowadza nowości i są one wykorzystywane bądź nie. Oczywiście konieczne jest wykorzystywanie nowych produktów które poprawiają jakość usługi, ale nie wpływa ona bezpośrednio na stan sprzedaży usługi.

e) groźby pojawienia się konkurencji - nie wykluczone że jest to najważniejszy czynnik wpływający na stan firmy. Pojawienie się konkurencji wiąże się ze stratą odbiorców. Ale idzie również za tym podniesienie jakości usług i wzmocnione przywiązanie do wykonywanych czynności i satysfakcji klienta. Pojawienie konkurencji mobilizuje załogę na wzmożonej pracy.

\section{Metoda prezentacji portfela produkcji - macierz BCG}

Macierz BCG to narzędzie marketingu do analizy możliwości rynkowych i własnych przedsięwzięć. W macierzy BCG wyznacza się dwa wymiary:

- Tempo wzrostu rynku - Granica jest na poziomie $10 \%$. Jeżeli stopa wzrostu rynku jest większa lub równa $10 \%$, to uważa się, że jest to wzrost znaczny.

- Względny udział w rynku - W porównaniu do największego konkurenta. Jeżeli udział liczony w przychodach jest główny konkurent, to nadaje mu się wartość $100 \%$. Przykładowo wartość $150 \%$ oznacza, że przychody z przedsięwzięcia są o $50 \%$ wyższe od głównego konkurenta.

Tempo wzrostu rynku, na którym działa firma w \%- 70\% zaś procentowy stosunek sprzedaży firmy do głównego konkurenta w \% - 140\%

\begin{tabular}{|c|c|}
\hline GWIAZDY & ZNAKI ZAPYTANIA \\
\hline DOJNE KROWY & PIESKI \\
\hline
\end{tabular}

Rys. 3. Zaznaczona pozycja ustugi na rynku

Źródto: opracowanie własne 
Gwiazdy - tempo wzrostu wyższe niż 10\% a względny udział rynku wyższy niż 100\%. Firma musi nadal dużo inwestować by utrzymać tytuł lidera na rynku. Słabe gwiazdy mogą być poważnym problemem. Możliwe strategie działania:

Gwiazdy - Utrzymywanie bycia liderem. W przypadku słabych Gwiazd należy przyjąć strategię redukowania wydatków na rozwój, tak aby dany biznes zaczął przynosić w końcu przepływy pieniężne.

\section{Analiza SWOT}

Kluczowym systemem stosowanym $\mathrm{w}$ analizie sytuacji przedsiębiorstwa jest analiza SWOT. Analiza SWOT to narzędzie, dzięki którym firma może zanalizować i rozpoznać własne słabe i silne strony (Strenghtsi Weaknesses), a także istniejące i potencjalne szanse i zagrożenia (Opportunities i Threats) płynące z otoczenia zewnętrznego.

Nazwa SWOT pochodzi od pierwszych liter słów określających w języku angielskim istotę przedmiotu analizy (tablice 3-5).

- $\mathbf{S}$ jak Strength- mocne strony które posiada organizacja, należy je odpowiednio wykorzystywać, sprzyjają one rozwojowi, a w chwili obecnej pozytywnie wyróżniają organizację $\mathrm{w}$ otoczeniu, są przewagą $\mathrm{w}$ stosunku do konkurencji,

- W jak Weakness- słabe strony organizacji, w przypadku braku ich eliminacji siły ich oddziaływania będą hamować rozwój organizacji,

- Ojak Opportunities - szanse- uwarunkowania, które dzięki umiejętnemu wykorzystaniu mogą wpływać pozytywnie na rozwój firmy,

- T jak Threats - zagrożenia dla organizacji, czynniki, które obecnie nie przeszkadzają $\mathrm{w}$ funkcjonowaniu, ale mogą przyczynić się do sprawności firmy i stać się zagrożeniem w przyszłości. 


\section{Quality. Production. Improvement}

Tabela 3. Analiza czynników SWOT

\begin{tabular}{|c|c|}
\hline $\begin{array}{l}\quad \text { Mocne Strony(S) } \\
\text { 1. Znacząca pozycja na rynku } \\
\text { 2. Utrzymana płynność finansowa } \\
\text { 3. Komunikacja z rynkiem } \\
\text { 4. Doświadczenie oraz wykwalifikowana } \\
\text { kadra } \\
\text { 5. Nowoczesne wyposażenie } \\
\text { 6. Estetyczny wizerunek firmy } \\
\text { 7. Dobra lokalizacja } \\
\text { 8. Własny lokal } \\
\text { 9. Doświadczenie w kierowaniu firmą } \\
\text { 10. Wykorzystanie nowoczesnego sprzętu } \\
\text { w diagnostyce } \\
\text { 11. Podpisana umowa z publicznym ubez- } \\
\text { pieczeniem } \\
\text { 12. Nowocześnie wyposażone gabinety } \\
\text { 13. Parking przy przychodni } \\
\text { 14. Własne laboratorium } \\
\text { 15. Aktualna strona internetowa } \\
\text { 16. Stali dostawcy }\end{array}$ & $\begin{array}{l}\qquad \text { Słabe Strony (W) } \\
\text { 1. Silna konkurencja na rynku } \\
\text { 2. Lokalizacja w niewielkiej miejscowości } \\
\text { 3. Słaby poziom marketingu } \\
\text { 4. Brak akcji promocyjnych, lub ich słabe } \\
\text { nagłośnienie } \\
\text { 5. Niekonkurencyjne ceny } \\
\text { 6. Braki w personelu - asystenci } \\
\text { 7. Niezdefiniowana grupa docelowa, } \\
\text { do której kierowana jest oferta firmy } \\
\text { 8. Brak specjalistów np. implantologów }\end{array}$ \\
\hline $\begin{array}{l}\text { Okazje (O) } \\
\text { 1. Pojawienie się nowych grup pacjentów- } \\
\text { studentów, obcokrajowców } \\
\text { 2. Poszerzenie oferty o usługi specjali- } \\
\text { styczne } \\
\text { 3. Możliwość poszerzenia zakresu usług } \\
\text { medycznych } \\
\text { 4. Reklama w dużych przedsiębiorstwach } \\
\text { 5. Organizowanie otwartych dni profilak- } \\
\text { tyki } \\
\text { 6. Rosnące zapotrzebowanie na lekarzy } \\
\text { specjalistów } \\
\text { 7. Stałe zapotrzebowanie na opiekę zdro- } \\
\text { wotną } \\
\text { 8. Osłabienie konkurencji } \\
\text { 9. Wzrost liczby mieszkańców } \\
\text { 10. Wzrost zarobków }\end{array}$ & $\begin{array}{l}\text { Zagrożenia (T) } \\
\text { 1. Możliwość pojawienia się nowych, } \\
\text { specjalistycznych przychodni, } \\
\text { 2. Częste zmiany przepisów prawnych } \\
\text { 3. Rosnące koszty utrzymania przychodni } \\
\text { 4. Brak wyspecjalizowanego personelu } \\
\text { 5. Rosnące zainteresowanie niekonwen- } \\
\text { cjonalnymi metodami leczenia } \\
\text { 6. Wzrastające ceny sprzętu medycznego } \\
\text { 7. Spadek liczby mieszkańców } \\
\text { 8. Zwiększenie bezrobocia } \\
\text { 9. Spadek zaufania pacjentów do lekarzy } \\
\text { w wyniku potencjalnego błędu lekar- } \\
\text { skiego }\end{array}$ \\
\hline
\end{tabular}

Źródto: opracowanie własne 
Zeszyty Naukowe

$\mathrm{Nr}$ 1(4)

Quality. Production. Improvement

Tabela 4. Strategiczna analiza SWOT

\begin{tabular}{|c|c|c|}
\hline & \begin{tabular}{l}
\multicolumn{1}{c}{ Atuty (S) } \\
1. Znacząca pozycja na rynku \\
2. Utrzymana płynność finansowa \\
3. Komunikacja z rynkiem \\
4. Doświadczenie oraz wykwalifi- \\
kowana kadra \\
5. Nowoczesne wyposażenie w \\
sprzęt \\
6. Estetyczny wizerunek firmy \\
7. Dobra lokalizacja \\
8. Własny lokal \\
9. Doświadczenie w kierowaniu \\
firmą \\
10. - Wykorzystanie nowoczesne- \\
go sprzętu w diagnostyce \\
11. Podpisana umowa z publicz- \\
nym ubezpieczeniem \\
12. Nowocześnie wyposażone \\
gabinety \\
13. Parking przy przychodni \\
14. Własne laboratorium \\
15. Aktualna strona internetowa \\
16. Stali dostawcy
\end{tabular} & \begin{tabular}{l}
\multicolumn{1}{c}{ Słabości (W) } \\
1. Silna konkurencja na rynku \\
2. Lokalizacja w niewielkiej miej- \\
scowości \\
3. Słaby poziom marketingu \\
4. Brak akcji promocyjnych, lub ich \\
słabe nagłośnienie \\
5. Niekonkurencyjne ceny \\
6. Braki w personelu - asystenci \\
7. Niezdefiniowana grupa docelowa, \\
do której kierowana jest oferta \\
firmy \\
8. Brak specjalistów np. implantolo- \\
gów
\end{tabular} \\
\hline $\begin{array}{l}\text { Okazje (O) } \\
\text { 1. Pojawienie się nowych grup } \\
\text { pacjentów- studentów, } \\
\text { obcokrajowców } \\
\text { 2. Poszerzenie oferty o usługi } \\
\text { specjalistyczne } \\
\text { 3. Możliwość poszerzenia } \\
\text { zakresu usług medycznych } \\
\text { 4. Reklama w dużych } \\
\text { przedsiębiorstwach } \\
\text { 5. Organizowanie otwartych } \\
\text { dni profilaktyki } \\
\text { 6. Rosnące zapotrzebowanie } \\
\text { na lekarzy specjalistów } \\
\text { 7. Stałe zapotrzebowanie na } \\
\text { opiekę zdrowotną } \\
\text { 8. Osłabienie konkurencji } \\
\text { 9. Wzrost liczby mieszkańców } \\
\text { 10. Wzrost zarobków }\end{array}$ & $\begin{array}{c}\text { Strategia SO } \\
\text { agresywna } \\
\text { S 1,3,7 O2,3,7,9,10 Zwiększenie } \\
\text { sprzedaży. } \\
\mathbf{S} \mathbf{4 , 5 , 1 0 ~ O ~ 3 , 1 , 1 0} \text { Opracowywanie } \\
\text { nowych usług. } \\
\mathbf{S} \mathbf{1 , 6} \text { O 2,3,4,5 Zwiększenie stopnia } \\
\text { znajomości praktyki } \\
\mathbf{S} \mathbf{1 , 7} \text { O } 6 \text { Łatwość uzupełniania } \\
\text { personelu, silniejszy związek } \\
\text { pracowników z firmą. } \\
\mathbf{S} \mathbf{4 , 1 4 , 1 6} \text { O 2,3 Większe } \\
\text { wykorzystanie mocy } \\
\text { produkcyjnych. }\end{array}$ & $\begin{array}{c}\text { Strategia WO } \\
\text { konkurencyjna } \\
\text { W } 1 \text { S 2,3,4 Zwiększenie udziału } \\
\text { w rynku. } \\
\text { W } 5 \text { O 1,5 Wejście na nowe rynki. } \\
\text { W } 4 \text { O 1 Działanie na rynkach mniej } \\
\text { wymagających pod względem } \\
\text { nakładów na promocję. } \\
\text { W } 8 \text { O 2,4 Pozyskanie bardzo } \\
\text { dobrych specjalistów } \\
\text { i sporządzanie odpowiednich ofert. } \\
\text { W 2,4 O 1,9,10 Zwiększenie stopnia } \\
\text { znajomości przychodni. }\end{array}$ \\
\hline $\begin{array}{l}\text { Zagrożenia (T) } \\
\text { 1. Możliwość pojawienia się } \\
\text { nowych, specjalistycznych } \\
\text { przychodni, } \\
\text { 2. Częste zmiany przepisów } \\
\text { prawnych } \\
\text { 3. Rosnące koszty utrzymania } \\
\text { przychodni } \\
\text { 4. Brak wyspecjalizowanego } \\
\text { personelu } \\
\text { 5. Rosnące zainteresowanie } \\
\text { niekonwencjonalnymi }\end{array}$ & $\begin{array}{c}\text { Strategia ST } \\
\text { konserwatywna } \\
\text { S 1,2,6 T 1,2,3 Czynniki } \\
\text { umacniające pozycję firmy. } \\
\text { S 2, 6 T } 5 \text { Zmniejszenie wahań } \\
\text { popytu spowodowanych } \\
\text { sezonowością. } \\
\text { S 5,8 T 6 Zapewnienie firmie } \\
\text { właściwego zaopatrzenia. } \\
\text { S 3,4 T 3,4 Możliwość obniżenia } \\
\text { cen wybranych produktów. } \\
\text { S 2,7 T } 7 \text { Stosowanie procedur } \\
\end{array}$ & $\begin{array}{l}\text { Strategia WT } \\
\text { defensywna } \\
\text { W 1,3,4 T 1,2 Spadek udziału w } \\
\text { rynku. } \\
\text { W 1,2 T 1,3 Zmniejszenie zysków } \\
\text { firmy. } \\
\text { W } 5 \text { T 3,4 Niedostosowanie oferty } \\
\text { pod względem jakościowo - } \\
\text { cenowym do sytuacji na rynku. } \\
\text { W } 5 \text { T } 6 \text { Wzrost kosztów } \\
\text { zaopatrzenia. }\end{array}$ \\
\hline
\end{tabular}




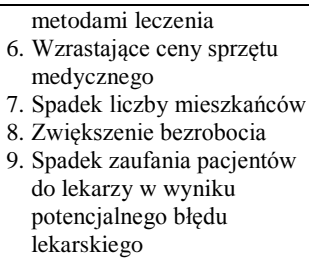

Źródto: opracowanie własne

Analiza SWOT określa, co może pomóc w realizacji celów firmy (silna strona lub możliwość) lub co może być przeszkodą, którą należy przezwyciężyć lub zminimalizować w celu osiągnięcia pożądanego rezultat. Cel wykonania analizy SWOT:

- budowa planów strategicznych,

- przeorientowanie dotychczasowego kierunku działalności organizacji,

- wypracowanie priorytetowego kierunku działania dostosowanego do zmieniających się warunków rynkowych

- rozpoznanie sytuacji wewnętrznej i zewnętrznej organizacji, aby w przypadku wykrytych niedoskonałości wprowadzić programy naprawcze,

- określenie kluczowych czynników, działań, które mają decydujący wpływ na rozwój firmy, a potem umacnianie ich jako źródła przewagi konkurencyjnej

- zapewnienie funkcjonowania jakości ( szerokie zastosowanie w ramach norm ISO). 
Tabela 5. Rozbudowana strategiczna analiza SWOT/TOWS

\begin{tabular}{|c|c|c|c|}
\hline Czynniki zewnętrzne & Waga & Czynniki wewnętrzne & Waga \\
\hline $\begin{array}{l}\text { Okazje (O) } \\
\text { 1.Pojawienie się nowych } \\
\text { grup pacjentów- stu- } \\
\text { dentów, obcokrajow- } \\
\text { ców } \\
\text { 2.Poszerzenie oferty o } \\
\text { usługi specjalistyczne } \\
\text { 3.Możliwość poszerzenia } \\
\text { zakresu usług me- } \\
\text { dycznych } \\
\text { 4.Reklama w dużych } \\
\text { przedsiębiorstwach } \\
\text { 5.Organizowanie otwar- } \\
\text { tych dni profilaktyki } \\
\text { 6.Rosnące zapotrzebowa- } \\
\text { nie na lekarzy specja- } \\
\text { listów } \\
\text { 7.Stałe zapotrzebowanie na } \\
\text { opiekę zdrowotną } \\
\text { 8.Osłabienie konkurencji } \\
\text { 9.Wzrost liczby mieszkań- } \\
\text { ców } \\
\text { 10.Wzrost zarobków }\end{array}$ & $\begin{array}{l}0,10 \\
0,05 \\
0,10 \\
0,10 \\
0,10 \\
0,10 \\
0,10\end{array}$ & $\begin{array}{l}\text { Atuty (S) } \\
\text { 1.Znacząca pozycja na } \\
\text { rynku } \\
\text { 2.Utrzymana płynność } \\
\text { finansowa } \\
\text { 3. Komunikacja z rynkiem } \\
\text { 4.Doświadczenie oraz } \\
\text { wykwalifikowana kadra } \\
\text { 5.Nowoczesne wyposaże- } \\
\text { nie w sprzęt } \\
\text { 6.Estetyczny wizerunek } \\
\text { firmy } \\
\text { 7.Dobra lokalizacja } \\
\text { 8. Własny lokal } \\
\text { 9.Doświadczenie w kiero- } \\
\text { waniu firmą } \\
\text { 10.Wykorzystanie nowo- } \\
\text { czesnego sprzętu w dia- } \\
\text { gnostyce } \\
\text { 11.Podpisana umowa z } \\
\text { publicznym ubezpiecze- } \\
\text { niem } \\
\text { 12.Nowocześnie wyposa- } \\
\text { żone gabinety } \\
\text { 13.Parking przy przychod- } \\
\text { ni } \\
\text { 14.Własne laboratorium } \\
\text { 15.Aktualna strona inter- } \\
\text { netowa } \\
\text { 16.Stali dostawcy }\end{array}$ & $\begin{array}{c}0,10 \\
0,20 \\
0,10 \\
0,05 \\
0,05 \\
0,02\end{array}$ \\
\hline Suma & 1,0 & Suma & 1,0 \\
\hline
\end{tabular}




\begin{tabular}{|c|c|c|c|}
\hline $\begin{array}{l}\text { Zagrożenia (T) } \\
\text { 1.Możliwość pojawienia } \\
\text { się nowych, specjali- } \\
\text { stycznych przychodni, } \\
\text { 2.Częste zmiany przepisów } \\
\text { prawnych } \\
\text { 3.Rosnące koszty utrzy- } \\
\text { mania przychodni } \\
\text { 4.Brak wyspecjalizowane- } \\
\text { go personelu } \\
\text { 5.Rosnące zainteresowanie } \\
\text { niekonwencjonalnymi } \\
\text { metodami leczenia } \\
\text { 6.Wzrastające ceny sprzętu } \\
\text { medycznego } \\
\text { 7.Spadek liczby mieszkań- } \\
\text { ców } \\
\text { 8.Zwiększenie bezrobocia } \\
\text { 9.Spadek zaufania pacjen- } \\
\text { tów do lekarzy w wy- } \\
\text { niku potencjalnego } \\
\text { błędu lekarskiego }\end{array}$ & $\begin{array}{r}0,05 \\
0,05 \\
0,15 \\
0,10\end{array}$ & $\begin{array}{l}\text { Słabości (W) } \\
\text { 1.Silna konkurencja na } \\
\text { rynku } \\
\text { 2.Lokalizacja w niewiel- } \\
\text { kiej miejscowości } \\
\text { 3.Słaby poziom marketin- } \\
\text { gu } \\
\text { 4.Brak akcji promocyj- } \\
\text { nych, lub ich słabe } \\
\text { nagłośnienie } \\
\text { 5.Niekonkurencyjne ceny } \\
\text { 6.Braki w personelu - } \\
\text { asystenci } \\
\text { 7.Niezdefiniowana grupa } \\
\text { docelowa, do której } \\
\text { kierowana jest oferta } \\
\text { firmy } \\
\text { 8.Brak specjalistów np. } \\
\text { implantologów }\end{array}$ & $\begin{array}{l}0,20 \\
0,15 \\
0,20 \\
0,20\end{array}$ \\
\hline Suma & 1,0 & Suma & 1,0 \\
\hline
\end{tabular}

Źródto: opracowanie własne

\section{Podsumowanie}

Drukowanie 3D daje możliwość tworzenia obiektów z niedostępną nigdy wcześniej na masową skalę precyzją oraz stosunkowo niską ceną w przeliczeniu na sztukę produktu, w małym stopniu uzależnioną od jego nakładu. Prowadzenie działalności innowacyjnej w podmiotach gospodarczych wymaga jednak ponoszenia zróżnicowanych nakładów inwestycyjnych. Zakup innowacyjnego sprzętu wymaga środków finansowych które przynoszą zwrot nałożonych nakładów wraz z dłuższym okresem użytkowania. Koszty poniesione na sprzęt przekładają się nie tylko na zysk finansowy przedsiębiorstwa, ale również jakość wykonywanych 
usług. Wymagane są zarówno zasoby ludzkie w postaci wykwalifikowanego personelu badawczego, oraz zasoby sprzętowe w postaci dostępu do specjalistycznej aparatury laboratoryjnej. Warto podkreślić, że branża medyczna jest obecnie uznawana za jedną z bardziej istotnych gałęzi gospodarki. Jednocześnie obserwuje się bardzo wysokie oczekiwania społeczne, wynikające $\mathrm{z}$ bieżących potrzeb pacjentów z długotrwałego cierpienia oraz leczenia. Społeczeństwo oczekuje wprowadzenia innowacji w medycynie, liczy na nowe rozwiązania, czeka na możliwość skorzystania z nowoczesnych terapii, chce mieć zapewniony dostęp do najnowszej aparatury ułatwiającej diagnostykę. Wykorzystanie technologii 3D w usługach stomatologicznych zapewnia wysoką konkurencyjność w branży i stawia przedsiębiorstwo na pozycji lidera. Zastosowanie innowacyjnych rozwiązań w branży medycznej jest możliwe. Szybkość pracy jest czynnikiem drugorzędnym, liczy się dokładność i wysoka jakość, którą można uzyskać dzięki implementacji nowoczesnych rozwiązań. Podstawą koncepcji jest eliminacja operacji które nie tworzą wartości dodanej.

\section{LITERATURA}

1. Bechthold L., Fischer V., Hainzlmaier A. IWSP. 2015. 3D Printing A Qualitative Assessment of Applications. RecentTrendsandtheTechnology's Future Potential Expertenkommission Forschung und Innovation (EFI) Geschäftsstelle, c/o Stifterverband für die Deutsche Wissenschaft

2. BORKOWSKI S., UlEWICZ R. 2009. Systemy produkcyjne. Instytut Organizacji i . Zarządzania w Przemyśle "ORGMASZ". Warszawa.

3. Brunello G., Sivolella S., Meneghello R., Ferroni L., Gardin C., Piattelli A., ZAVAN B., Bressan E. 2016. Powder-based 3D printing for bone tissue engineering. Biotechnology Advances, In Press, Corrected Proof.

4. Duan, B., Hockaday, L.A., KAng, K.H.\&Butcher, J.T. 2013. 3D bioprinting of heterogeneous aortic valve conduits with alginate/gelatin hydrogels. J. Biomed. Mater. Res. A101, 1255-1264 
5. SANCHEZ L., BlANCO B. 2014.Three decades of continuous improvement Three decades of continuous improvement. Total Quality Management \& Business Excellence, Vol. 25, No. 9, 986-1001

6. THOMPSON J.R., KORONACKI J., NIECKUŁA J. 2006.Techniki zarządzania jakościa od Shewharta do metody Six Sigma. ELIT, Warszawa.

7. WAGNER L. 2008. Zastosowanie technik warstwowych w stomatologii estetycznej. PWN. Warszawa 2008. 